\title{
An approach towards the knowledge of Iberian high-mountain calcareous grasslands
}

\author{
Rosario G. Gavilán (*), Estrella Díez-Monsalve (*), José Luis Izquierdo (**), \\ Alba Gutiérrez-Girón (*), Federico Fernández-González (***) \& \\ Daniel Sánchez-Mata (*)
}

\begin{abstract}
Gavilán, R.G., Díez-Monsalve, E., Izquierdo, J.L., Gutiérrez-Girón, A., Fernández-González, F. \& SánchezMata, D. An approach towards the knowledge of Iberian high-mountain calcareous grasslands. Lazaroa 33: 43-50 (2012).

We have carried out a study on the pastures growing at high altitudes on calcareous substrata in the central-eastern Iberian Peninsula. The study comprised two areas: the Gúdar and Javalambre mountain areas, and the calcareous outcrops of the Sierra de Guadarrama. Two datasets were analysed: relevés taken in the Sierra de Guadarrama in the summer of 2010; and the relevés of Rivas Goday \& Borja (1961) above $1700 \mathrm{~m}$ of altitude. The results highlighted the similarities and differences between both datasets, and we have recognized the new association Festuco curvifoliae-Astragaletum mutici for the Sierra de Guadarrama high-mountain calcareous grasslands, with a presence on both types of substrata.
\end{abstract}

Keywords: Community ecology, basophilous grasslands, alpine vegetation, Mediterranean vegetation, new association, Spain, Gúdar y Javalambre massif, Sierra de Guadarrama.

Resumen: Gavilán, R.G., Díez-Monsalve, E., Izquierdo, J.L., Gutiérrez-Girón, A., Fernández-González, F. \& Sánchez-Mata, D. Una aproximación al conocimiento de los pastizales calcícolas de la alta montaña ibérica. Lazaroa 33: 43-50 (2012).

Hemos llevado a cabo un estudio de los pastizales de alta montaña sobre sustrato calcáreo en las montañas del centroeste de la Península Ibérica. Dos áreas han sido estudiadas, el macizo de Gúdar y Javalambre y los afloramientos calcáreos de la Sierra de Guadarrama. Se han comparado dos conjuntos de inventarios, los de la Sierra de Guadarrama que hemos levantado en el año 2010 y los del macizo de Gúdar y Javalambre de Rivas Goday \& Borja (1961) tomados por encima de $1700 \mathrm{~m}$ de altitud. Los resultados muestran las similitudes y diferencias de ambos macizos, a partir de los cuales hemos diferenciado una nueva asociación Festuco curvifoliae-Astragaletum mutici, para describir los pastizales ricos en caméfitos sobre substratos calcáreos con presencia de silicatos de la Sierra de Guadarrama.

Palabras clave: Ecología de las comunidades, pastos basófilos, vegetación de alta montaña, vegetación Mediterránea, España, Macizo de Gúdar y Javalambre, Sierra de Guadarrama.

\section{INTRODUCTION}

The survival of high-mountain plant communities is currently under threat from a range of causes, all of which have an anthropic origin and can be grouped under the phenomenon known as global change. This is a flora with a large number of endemisms, formed mainly by perennial species which are usually very old and slow-growing
(PAUli \& al., 2004; GAVILÁN, 2010). The assessment of some of their abiotic and biotic features has not been studied in depth in relation to their current degree of threat from climate change and their predicted extinction rates (GAVILÁN \& al., 2002; EsCUDERO \& al., 2004; GUTIÉRREZ-GIRÓN \& GAVILÁN, 2010).

The effects of global climate change on these organisms and on the communities they form are

\footnotetext{
* Departamento de Biología Vegetal II. Facultad de Farmacia. Universidad Complutense. E-28040 Madrid. Email: rgavilan@farm.ucm.es; estrella.diez.monsalve.sanchez@gmail.com; aggiron@farm.ucm.es; dsmata@farm.ucm.es

** Parque Natural de Peñalara. E-28749 Madrid. Email: jlizquierdo@parquenaturalpenalara.org

*** Facultad de Ciencias del Medio Ambiente. Universidad de Castilla-La Mancha. E-45071 Toledo. E-mail: Federico.fernandez@uclm.es
} 
still not well known, but alpine areas can provide an ideal natural laboratory for ecological research into climate impact, as they are fragile environments where biodiversity losses may be considerable due to the high degree of endemism and the spatially limited distribution area of many highmountain species (THEURILLAT \& GUISAN, 2001; PAUli \& al., 2004; GAVILÁN \& GUTIÉRREZ-GiróN, 2009).

As evidence of the change that has been observed in the high mountains, orophytes, in general, are expected to face a downward trend, while species that are more or less adapted to warmer conditions will show positive trends, and their presence is predicted to increase. This fact has not been found in isolated mountain systems but on larger scales, and especially in temperate Europe during the last decade (GOTTFRIED \& al., 2012). Furthermore, the mean of the species whose niche is found at high altitudes has shifted upward. However, this trend is reversed depending on the location of the mountain, and species richness in boreal (circumboreal) or temperate areas has been quantified into 3.9 species in the area as a whole, compared to the response negative (-1.4 species) in the mountains of southern Europe with a Mediterranean climate, probably due to the reduced availability of water in these areas in the last decade. The loss of biodiversity in Europe is therefore a cause for concern, as although there may be an average increase in all mountain areas, there appears to be a clear and continuous decline in species richness in Mediterranean areas, which are also the richest sources of endemic plants (WALTER \& al., 2005, PAULi \& al., 2012).

The objective of this study was to determine the relationships between two relatively distant summit areas (approx. $300 \mathrm{~km}$ ) in central Spain, through the comparison of two high-mountain grasslands growing on calcareous substrata. The two mountain ranges were the Gúdar and Javalambre massif (Teruel), and the Sierra de Guadarrama (Madrid). The former has been widely studied and described, and comprises a landscape dominated by calcareous rocks, while the second is restricted to a small valley in a siliceous mountain range, with the presence of both substrata. From this comparison we have obtained additio- nal information that has allowed us to reach various syntaxonomical conclusions with regard to vegetation growing at that altitude.

\section{MATERIALS AND METHODS}

This study has been conducted in the upper altitudinal areas of two mountain ranges in central Spain as described above: the Sierra de Guadarrama in the Madrid region, and the Gúdar and Javalambre massif in Teruel.

The Sierra de Guadarrama is characterized by a granite and gneiss lithology, and has a typical Mediterranean, silicicolous flora. It also has intercalations of metamorphic and sub-volcanic carbonated rocks in the main Palaeozoic massif that cause these areas to have a particular flora at altitudes below $1200 \mathrm{~m}$. However there is a tight band of dolomitic marbles with calcic silicate intercalations between glandular orthogneisses in the Artiñuelo valley from $1550 \mathrm{~m}$ to $2100 \mathrm{~m}$. These basic outcrops are buried by morainic deposits and slope colluviums (PÉREZ BADIA \& al., 1998).

The average annual precipitation of the nearby meteorological stations in the Puerto de Navacerrada pass $(1894 \mathrm{~m})$ is $1330 \mathrm{~mm}$, concentrated from early October to late May, usually in the form of snow; and the average annual temperature is $2.5^{\circ} \mathrm{C}$. However, as a characteristic of this climate, the snow cover is not constant over this period of time, and vegetation is further influenced by ice and wind. There is also a pronounced drought season (less than $10 \%$ of total annual rainfall), typical of a Mediterranean territory.

The Gúdar and Javalambre massif is characterized by Triassic and Cretaceous calcic soils. Due to its rainy climate, there is an abundance of molasses and sandstones with low content of alkaline-earth carbonates which are decarbonated on the surface. Some siliceous sandstone rocks are found in this area, but at lower altitudes (RIVAS GODAY \& BORJA, 1961). Its particular flora is due to the Mediterranean climate with mild summers -although with harsh winters with snow and frosts-, average monthly precipitations of 31.25 $\mathrm{mm}$, and average monthly temperatures of $6.7^{\circ} \mathrm{C}$ in winter and $17^{\circ} \mathrm{C}$ in summer $(900 \mathrm{~m})$. 
For the vegetation study we took phytosociological relevés in the Sierra de Guadarrama in 2010 following the Braun-Blanquet method (BRAUN-BLANQUET, 1979). For the vegetation of the Gúdar and Javalambre massif we used the phytosociological relevés of all plant communities described above $1700 \mathrm{~m}$ and published by Rivas GODAY \& BORJA (1961).

We then analysed all these together (134 relevés and 408 species) using multivariable methods (DCA, Detrended Correspondence Analysis) with CANOCO 4.5 (TER BRAAK AND SMILAUER, 2002).

For the nomenclature of taxa we referred to Castroviejo \& al. (1986-2010) and Tutin \& al. (1964-1993); for the moss species to SMITH (1996) and HofMANN (1998) and for the lichen taxa to PURvis \& al. (1992) and the index fungorum (http://www.indexfungorum.org).

\section{RESULTS}

The first DCA exploratory analysis done on the large dataset of both localities (Figure 1) showed a high environmental gradient for the first axis (20.620), separating six groups which very roughly correspond to five plant communities differing in floristic composition and habitat type. There is a large group of relevés in the centre of the diagram from Gúdar and Javalambre showing somewhat unclear relationships between its component relevés and the rest of groups, probably due to its size and the large environmental gradient obtained throughout the first axis of the DCA. In a second step we decided to extract and re-ordinate it.

Figure 1 showed the main separation of groups along the first axis, although the second axis separated group three, as explained below:

Group 1. This includes 22 relevés from the Gúdar and Javalambre massif. It is situated at the left of the diagram, close to coordinate 0 . The relevés were classified by RIVAS GODAY \& BORJA (1961) as Linario-Euphorbietum graecae. They are rich in ruderal plants, some of them with a wide distribution, such as Papaver rhoeas, Lolium rigidum, Melilotus albus, Neatostema apulum, Anthemis arvensis, Buglossoides arvensis, Vicia angustifolia, Chenopodium album, etc. There are also some basophilous species linked to calcareous plant communities related to similar resource requirements: field crops, poor environments and ruderal habitats. Species belonging to these communities include Thlaspi arvense, Neslia paniculata, Caucalis platycarpos, Centaurea scabiosa, Alyssum simplex, Androsace maxima, Bunium bulbocastanum, Bupleurum rotundifolium, Camelina microcarpa, etc.

Group 2. This is a small uniform group of only seven relevés from the Gúdar and Javalambre massif that appears in the middle of Figure 1. Relevés are rich in Melica minuta, Micromeria fruticosa or Jasonia glutinosa which have a preference for calcareous rocks. In addition we have also

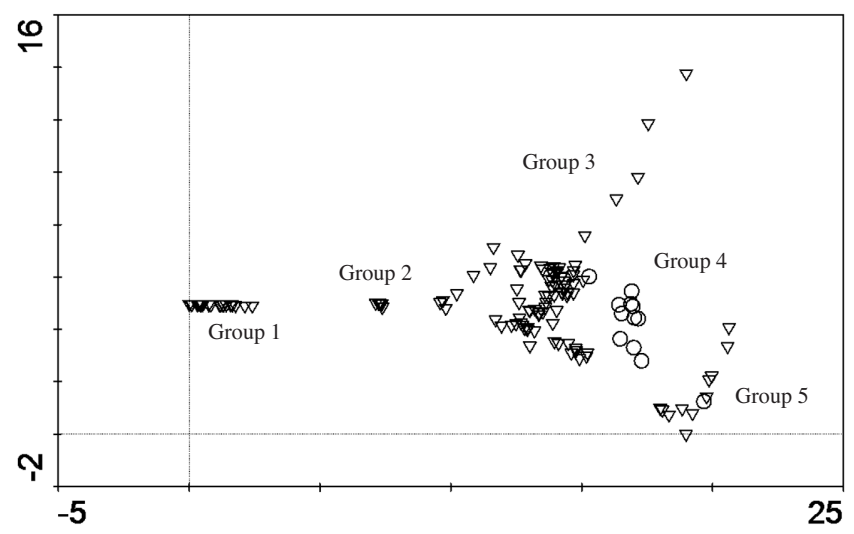

Figure 1. - First two axes of the DCA applied to relevés from Gúdar and Javalambre over 1700 m of altitude (Rivas Goday \& Borja 1961), and to relevés from the Sierra de Guadarrama (see Tables 1 and 2). 
found Bupleurum fruticescens, Erica multiflora, Hypericum ericoides, Juniperus phoenicea, etc., also with a preference for calcareous cliffs or in permanent communities (i.e. Juniperus phoenicea).

Group 3. This is also a small group of relevés separated in the upper right corner of the diagram, along the second axis. It is composed of relevés from both localities. The most abundant species are: Allium senescens subsp. montanum, Asplenium ruta-muraria, A. trichomanes, Ceterach officinarum, Chaenorhinum segoviense, Cystopteris fragilis, Iberis saxatilis, Melica minuta, Seseli montanum, Stipa lagascae, S. offneri, S. pennata, Telephium imperati and Teucrium chamaedrys.

Group 4. This is a group from the Sierra de Guadarrama. It is situated very close to the large central group, and shows some kind of relationships with relevés included in this group. It has a mixture of calcicolous and silicicolous species dominated by Astragalus nevadensis subsp. muticus, Dianthus gredensis, Festuca curvifolia, Festuca iberica, Acinos alpinus, Agrostis delicatula, Arenaria erinacea, Astragalus incanus subsp. nummularioides, Avenula sulcata, Bromus ramosus, Carduus carpetanus, Cetraria aculeata, Galium idubedae, Jurinea humilis, etc.

Group 5. This is a group of twelve relevés from the Gúdar and Javalambre massif. It is located at the lower right corner of the diagram (Figure 1). It was classified by RIVAS GODAY \& BORJA (1961) in Caricion davallianae due to the presence of Carex davalliana, together with other Carex spe- cies, as well as various Juncus species (J. articulatus, J. conglomeratus), Carum verticillatum, Cratoneuron commutatum, Eleocharis quinqueflora, Epipactis palustris, etc.

The large and heterogeneous group from the Gúdar and Javalambre massif that appears in the centre of Figure 1 was extracted together with group 4 from the Sierra de Guadarrama, with a total of 50 relevés. They were ordinated again by DCA (Figure 2). The results showed five groups that were well-separated along the first two axes (Figure 2). The first axis still showed a long ecological gradient (12.209) reflecting the different ecological situations of the relevés and the fact that this large group is composed of different plant communities:

Group 1. This is a heterogeneous group formed by 10 relevés from Gúdar and Javalambre that were widely spread in the DCA. It is composed of relevés that are rich in species which grow in wide rock fissures, calcareous rocks and shrublands in stony soils.

In the case of groups 2 and 3, both from the summits, they do not show separation along the first axis but the second. Group 2 is from the Sierra de Guadarrama and group 3 is from Gúdar and Javalambre. They share some species such as Astragalus nevadensis subsp. muticus, Arenaria erinacea, Poa ligulata, Koeleria vallesiana and Dianthus pungens subsp. brachyanthus.

Group 2. Formed by 12 relevés from the calcareous summit areas of Sierra de Guadarrama. It is located at the top of Figure 2 and is charac-

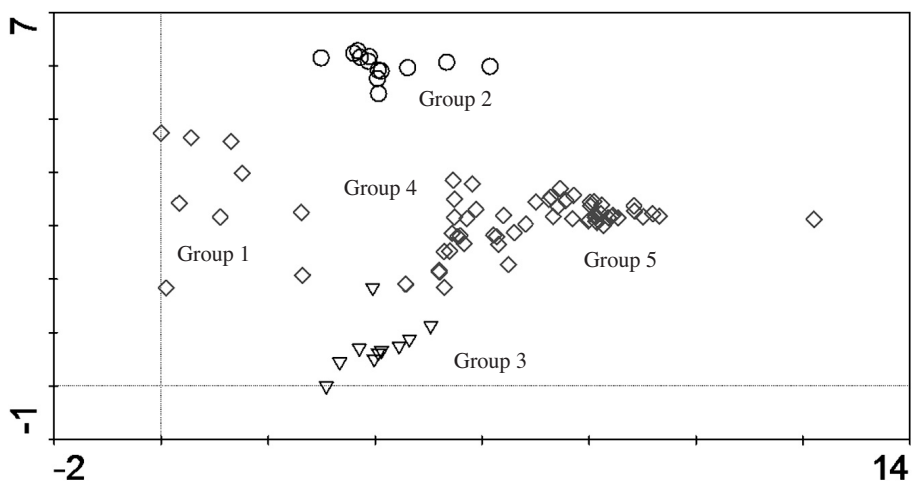

Figure 2. - First two axes of the DCA applied to the central relevés of Figure 1 (see text for more explanations). 
terized by the presence of Festuco-Ononidetea species such as Astragalus nevadensis subsp. muticus, Dianthus pungens subsp. brachyanthus, Arenaria erinacea or Poa ligulata, together with silicicolous species of Festucetea indigestae such as Festuca curvifolia, Leucanthemopsis pallida and Armeria caespitosa.

Group 3. This is also a group of 12 relevés from the Gúdar and Javalambre summits. As mentioned above, it shares species with group 2 (see paragraph above) and both groups reflect the alpine plant communities on calcareous substrata. The differential floristic composition of these relevés comprises perennial and sometimes cushion plants such as Armeria godayana, Artemisia pedemontana, Erinacea anthyllis and Sideritis glacialis, together with other basophilous therophytes or hemicryptophytes such as Arenaria obtusiflora subsp. ciliaris, Avenula pratensis, Carex hallerana, etc.

Group 4. This is a group of 21 relevés from Gúdar and Javalambre (RIVAs GODAY \& BORJA, 1961) dominated by Astragalus austriacus and Festuca hystrix. They are very rich grasslands, with numerous species such as Arenaria serpyllifolia, Avenula bromoides, Bromus erectus, Campanula rotundifolia, Carex hallerana, Fragaria vesca, Galium idubedae, Thymus serpyllum and Viola rupestris. They were described as Astragaleto-Ononideto cenisiae and Poeto ligulatae-Festucetum hystricis, but have not been separated by the present DCA (Figure 2).

Group 5. This also has a high number of relevés (20) corresponding to mown-grass communities from Gúdar and Javalambre. In the diagram it shows some overlapping with group 4, indicating the transition from Festuca hystrix grasslands to their present condition when correctly managed. They are rich in Cirsium acaule and Onobrychis viciaefolia, in addition to Phleum pretense, Scabiosa tomentosa, Brachypodium phoenicoides, Carex hallerana, etc.

\section{DISCUSSION}

The presence of dolomite marbles between the granite outcrops typical of a siliceous massif such as the Sierra de Guadarrama has given rise to a flora and thus to a type of vegetation that can be considered very specific to the central Iberian Peninsula, and particularly if we consider the situation of these marbles at altitudes of over $2000 \mathrm{~m}$. The basophilous species that are found there may be related with the high-mountain flora of the nearest calcareous mountain, the Gúdar and Javalambre massif. This is the case of Astragalus nevadensis subsp. muticus, Teucrium expassum, Galium idubedae, Iberis saxatilis, etc. that are present in both localities, and with a restricted distribution in calcareous high-mountain areas above 1500 m (PÉREZ BADIA \& al., 1989).

Thus after the study and analysis of the relevés from both mountains, not only the flora but the vegetation proved to have some relationships ( $\mathrm{Fi}$ gure 2). This is the case with groups 2 and 3 , both from the highest altitudes of the two mountains, which showed no separation along the first axis. This fact may be related to a similar physiognomic type of plant community, but it is well separated along the second axis, reflecting the differences observed in vegetation growing in a different mountain range. Group 2 is from the Sierra de Guadarrama and group 3 from the Gúdar and Javalambre massif. They have some of these species in common, such as Arenaria grandiflora, Arenaria erinacea, Koeleria vallesiana, Poa ligulata, Bupleurum ranunculoides, Galium idubedae, Dianthus pungens subsp. brachyanthus and Astragalus nevadensis subsp. muticus.

With regard to group 2 (Figure 2) we propose a new association: Festuco curvifoliae-Astragaletum mutici ass. nova hoc loco (Table 1, holotypus inv. 5), led by Astragalus nevadensis subsp. muticus and Festuca curvifolia, the former a calcareous, suffruticose chamaephyte found in both ranges; the second a silicicolous grassland species that leads the psycroxerophilous high-mountain pastures of the Sierra de Guadarrama and has a geographical distribution restricted to siliceous ranges in central Spain. They are described as central Spain oro- and cryoromediterranean calcicolous grasslands with influence of silicicolous grassland species on cryoturbaded soils. We have included the new association in Festuco hystri- 
Table 1

Festuco curvifoliae-Astragaletum mutici ass. nova

(Sideritido-Arenarion, Festuco hystricis-Poetalia ligulatae, Festuco histricis-Ononidetea striatae)

\begin{tabular}{llllllllllll}
\hline Altitude $(1=10 \mathrm{~m})$ & 199 & 199 & 200 & 200 & 199 & 199 & 199 & 198 & 176 & 177 & 178 \\
Area $\left(\mathrm{m}^{2}\right)$ & 10 & 10 & 2 & 10 & 4 & 10 & 2 & 25 & 6 & 4 & 8 \\
Cover $(\%)$ & 50 & 70 & 80 & 80 & 70 & 80 & 70 & 85 & 90 & 90 & 80 \\
Exposure $\left({ }^{\circ}\right)$ & 300 & 330 & 250 & 310 & 250 & 330 & 250 & 170 & 240 & 230 & 90 \\
Relevé N. & 1 & 2 & 3 & 4 & 5 & 6 & 7 & 8 & 9 & 10 & 11 \\
\hline
\end{tabular}

Festuco-Ononidetea characteristics

Astragalus nevadensis subsp. muticus

Poa ligulata

Teucrium expassum

Seseli montanum

Arenaria erinacea

Iberis saxatilis

Dianthus pungens subsp. brachyanthus

Koeleria vallesiana

Veronica jabalambrensis

Arenaria grandiflora

Inula montana

Valeriana tuberosa

Bupleurum ranunculoides

Festucetea indigestae differentials

Festuca curvifolia

Jurinea humilis

Leucanthemopsis pallida

Avenula sulcata

Armeria caespitosa

Companions

Sedum album

Acinos alpinus

Lotus corniculatus

Scleranthus perennis

Tulipa australis

Bromus ramosus

Cerastium arvense

Ranunculus bulbosus var. cacuminalis

Hieracium pilosella

Galium idubedae

Astragalus incanus

Hernaria cinerea

Sedum tenuifolium

Polytrichum piliferum

Cetraria aculeata

Thymus zygis

Silene legionensis

Carduus carpetanus

Agrostis capillaris

Festuca iberica

Saxifraga carpetana

Hernaria glabra

Agrostis delicatula

Ceratodon purpureus

$\begin{array}{lllllllllll}. & . & + & . & 4 & 4 & . & 3 & 2 & . & 2 \\ + & 1 & 4 & 3 & 2 & . & 3 & . & 1 & 1 & + \\ . & . & 1 & + & 1 & 2 & . & . & 1 & 3 & + \\ 1 & 1 & + & 1 & + & 1 & + & . & . & . & . \\ 3 & 2 & 2 & 2 & 2 & 1 & 1 & . & . & . & . \\ . & . & 2 & . & 1 & . & 1 & . & . & . & . \\ 3 & 3 & . & + & + & + & + & . & . & . & . \\ . & . & . & . & 3 & 1 & . & . & . & . & . \\ . & . & . & . & + & + & . & . & . & . & . \\ . & . & . & . & . & . & . & . & . & . & 1 \\ . & . & . & . & . & . & . & . & . & . & + \\ . & . & . & + & . & . & . & . & . & . & . \\ . & . & + & . & . & . & . & . & . & . & .\end{array}$

Other species: Festucetea indigestae companions: Koeleria crassipes + in 1, Sesamoides purpurascens + in 2 and Hieracium castellanum + in 10. Companions: Luzula hispanica 1 in 2; Sedum brevifolium 1, Poa bulbosa + in 4 ; Centaurea triumfetti and Carex vulpina 1, Cruciata laevipes and Nardus stricta + in 8; Petrorhagia nanteuilii + in 10; Melica magnolii 2, Potentilla neumanniana 1, Lactuca viminea, Allium sphaerocephalon, Chaenorhinum segoviense + in 10

Localities: All relevés from Sierra de Guadarrama (Collado de la Flecha). Holotypus ass. inv. 5. 


\section{Table 2}

Synthetic table of Mediterranean high-mountain, calcareous pastures of central Spain

Sideritido-Arenarietum Rivas Goday \& Borja 1961 (1)

Paronychio-Artemisietum Rivas Goday \& Borja 1961 (2)

Festuco curvifoliae-Astragaletum mutici ass. nova (3)

(Sideritido-Arenarion, Festuco-Poetalia ligulatae, Festuco-Ononidetea striatae)

\begin{tabular}{|c|c|c|c|}
\hline Number of synthetic relevé & 1 & 2 & 3 \\
\hline \multicolumn{4}{|l|}{ Festuco-Ononidetea characteristics } \\
\hline Arenaria erinacea & $\mathrm{V}$ & 2 & IV \\
\hline Astragalus nevadensis subsp. muticus & III & 1 & III \\
\hline Poa ligulata & III & 2 & V \\
\hline Koeleria vallesiana & $\mathrm{V}$ & 1 & I \\
\hline Dianthus pungens subsp. brachyanthus & $\mathrm{V}$ & 2 & III \\
\hline Anthyllis vulneraria s.l. & I & 1 & . \\
\hline Arenaria grandiflora & III & . & I \\
\hline Sideritis fontqueriana & V & 2 & . \\
\hline Festuca hystrix & $\mathrm{V}$ & 2 & . \\
\hline Carex hallerana & II & 1 & . \\
\hline Ononis cristata & IV & 1 & . \\
\hline Fumana procumbens & I & . & . \\
\hline Erinacea anthyllis & I & . & . \\
\hline Teucrium expassum & . & . & IV \\
\hline Veronica jabalambrensis & . & . & I \\
\hline Chaenorrhinum segoviense & . & . & I \\
\hline Inula montana & . & . & I \\
\hline Bupleurum ranunculoides & . & . & I \\
\hline \multicolumn{4}{|l|}{ Festucetea indigestae differentials } \\
\hline Leucanthemopsis pallida & . & . & II \\
\hline Festuca curvifolia & . & . & III \\
\hline \multicolumn{4}{|l|}{ Companions } \\
\hline Galium idubedae & IV & 2 & III \\
\hline Jurinea humilis & II & . & IV \\
\hline Astragalus incanus & I & . & II \\
\hline Iberis saxatilis & I & . & II \\
\hline Petrorhagia nanteuilii & I & . & I \\
\hline Festuca aragonensis & $\mathrm{V}$ & 1 & . \\
\hline Potentilla cinerea & $\mathrm{V}$ & 2 & . \\
\hline Avenula pratensis & III & 2 & . \\
\hline Coronilla minima & IV & 1 & . \\
\hline Helianthemum oelandicum s.l. & II & 2 & . \\
\hline Thymus serpyllum & $\mathrm{V}$ & 2 & . \\
\hline Ononis pusilla & III & 1 & . \\
\hline Teucrium aragonense & III & 1 & . \\
\hline Paronychia capitata & III & 2 & \\
\hline
\end{tabular}

Other species: Festucetea indigestae differentials: $\mathrm{Ar}$ meria caespitosa, Sesamoides purpurascens, Allium sphaerocephalon, Koeleria crassipes, Sesamoides purpurascens, Hieracium castellanum and Avenula sulcata I in 3; Companions: Plantago maritima subsp. serpentina and Artemisia pedemontana II, Carduncellus monspeliensium III in 1; Sedum album V, Bromus ramosus,
Scleranthus perennis, Seseli montanum and Tulipa australis III, Cerastium arvense, Cetraria aculeata, Hieracium pilosela, Polytrichum piliferum and Ranunculus bulbosus var. cacuminalis II, Potentilla neumanniana, Centaurea triumfetti, Sedum tenuifolium, Agrostis delicatula, Ceratodon purpureus, Hernaria glabra, Poa bulbosa, Saxifraga carpetana, Valeriana tuberosa, Sedum brevifolium, Cruciata laevipes, Lactuca viminea, Carex cuprina, Carduus carpetanus, Hernaria cinérea, Thymus zygis, Silene legionensis, Luzula hispanica, Festuca ibérica and Melica magnolii I in 3. Only companions with more than I in relevés 1 and 2 are included. Procedence of relevés: 1 and 2: Rivas Goday \& Borja Carbonell 1961, Cuadro 14 and 15; 3: Table 1.

cis-Ononidetea striatae Rivas-Martínez \& al. 2002 and corresponding subsyntaxa (Festuco hystricis-Poetalia ligulatae Rivas-Martínez \& al. 2002, Sideritido-Arenarion; Mucina \& al., in press.) due to its higher proportion of basophilous than silicicolous species, taking also into account some data on soils (Ca: $38.86 \mathrm{cmol} / \mathrm{Kg}, \mathrm{pH}$ $\left(\mathrm{H}_{2} \mathrm{O}\right)$ : 6.59) typical of calcareous soils. From Table 1 we should also highlight the greater cover values of silicicolous species when there is lower cover or an absence of basophilous species (i.e. relevés 1 or 2).

Rivas GODAY \& BORJa (1961) described two associations, Sideriteto-Arenarietum erinaceae and Paronychieto-Artemisietum lanatae, for alpine, calcareous pastures in Iberian mountains. They are rich in cushion chamaephytic species such as Sideritis glacialis, Arenaria erinacea, Artemisia pedemontana, Erinacea anthyllis and Dianthus pungens subsp. brachyanthus, together with other perennial species such as Festuca aragonensis or Astragalus sempervirens subsp. muticus. Differences between both associations seems to be due to more management pressure for the second (RIVAS GODAY \& BORJA, 1961), but we have not detect it in our analysis.

\section{ACKNOWLEDGEMENTS}

We wish to thank Prudence Brooke-Turner for revising the English text. This research has been funded by the Madrid Regional Government (REMEDINAL2 Project: S2009/AMB1783) and the Spanish National Science Ministry, MICINN (BIOALPI Project: CGL 2008-904/BOS). 


\section{FLORISTIC APPENDIX}

We list here in alphabetical order taxa used when they did not coincide with Flora Iberica (CASTROVIEJO \& al., 1986-

2010) and Flora Europaea (TuTIN \& al., 1964-1993).

Avenula sulcata (Gay ex Boiss.) Dumort

Festuca curvifolia Lag. ex Lange

Melica magnolii Gren. \& Godr.

Sideritis fontqueriana $=$ Sideritis glacialis Boiss. subsp. fontqueriana Obón \& D. Rivera 1994

\section{REFERENCES}

Braun-Blanquet, J. - 1979 - Fitosociología. Bases para el estudio de las comunidades vegetales - Ed. Blume, Madrid. 820 p.

Castroviejo, S. \& al. - 1986-2010 - Flora Iberica. Plantas vasculares de la Península Ibérica e Islas Baleares. R. Jard. Bot., CSIC, Madrid.

Escudero, A., Giménez-Benavides, L., Iriondo, J.M., Rubio, A. -2004- Patch dynamics and islands of fertility in a high mountain Mediterranean community - Arct. Antarct. Alp. Res. 36: 518-527.

Gavilán, R.G., Sánchez-Mata, D., Escudero, A. \& Rubio, A. -2002 - Spatial structure and interspecific interactions in Mediterranean high mountain vegetation (Sistema Central, Spain) - Israel J. Plant Sci. 50: 217-228

Gavilán, R.G., Gutiérrez-Girón, A., Izquierdo, J.L., Vielva, J., Fernández-González, F. \& Sánchez-Mata, D. 2009- Rare alpine plants of Sierra de Guadarrama: Which and where are their closest relatives? - Proc. 52nd IAVS Symp.: 171.

Gavilán, R.G. \& Gutiérrez-Girón, A. -2009-The Importance of Mediterranean Alpine Biodiversity in Central Spain - Mount. F. Bull. 9(2): 54-55.

Gavilán, R.G. - 2010 - Facilitation: an important outcome for alpine Mediterranean Biodiversity - In: Spehn, E.M., Rudmann-Maurer, K., Korner, C. \& Maselli, D. (Eds.). Mountain Biodiversity and global change (Functional significance of mountain Biodiversity). Pp. 22. GMBA-Diversitas, Basel.

Gottfried, M., Pauli, H., Futschik, A.,Akhalkatsi, M., Barancok, P., Benito, J.L., Coldea, G., Dick, J., Erschbamer, B., Fernández, M.R., Kazakis, G., Krajci, J., Larsson, P., Mallaun, M., Michelsen, O., Moiseev, D., Moiseev, P., Molau, U., Merzouki, A., Nagy, L., Nakhutsrishvili, G., Pedersen, B., Pelino, G., Puscas, M., Rossi, G., Stanisci, A., Theurillat, J.P., Tomaselli, M., Villar,L., Vittoz, P., Vogiatzakis, I., Grabherr, G. 2012- Continent-wide response of mountain vegetation to climate change - Nature Climate Change 2: 111-115.

Gutiérrez-Girón, A. \& Gavilán, R.G. -2010 - Spatial patterns and interspecific relations analysis help to better understand species distribution patterns in a Mediterranean high mountain grassland - Plant Ecol. 210: 137-151.

Hofmann, H. - 1998 - A monograph of the genus Homalothecium (Brachytheciaceae, Musci) - Lindbergia 23:119-159.
Mucina, L., Dierssen, K., Bültmann, H., Dengler, J., Gavilán, R.G.,Theurillat, J.P. et al. -in prep.- Vegetation of Europe: Hierarchical floristic classification system, ecology, and distribution of the high-rank syntaxa of plant, algae and fungal communities. Appl. Veg. Sci.

Pauli, H., Gottfried M, Hohenwallner D, Reiter, K., Casale, R. \& Grabherr, G. - 2004 - The GLORIA field manualmulti summit approach, Luxembourg. http://www.gloria.ac.at/res/Gloria_home/.

Pauli, H., Gottfried, M., Dullinger, S., Abdaladze, O., Akhalkatsi, M., Benito, J.L., Coldea, G., Dick, J., Erschbamer, B., Fernández, MR., Goshn, D., Holten, J.I., Kanka, R., Kazakis, G., Kollár, J., Larsson, P., Moiseev, P., Moiseev, D., Molau, U., Molero Mesa, J., Nagy, L., Pelino, G., Puscas, M., Rossi, G., Stanisci, A., Syverhuset, A.O., Theurillat, J.P., Tomaselli, M., Unterluggauer, P., Villar, L., Vittoz, P., Grabherr, G. -2012- Recent Plant Diversity Changes on Europe's Mountain Summits Science 336: 353-355.

Pérez Badia, R., Gavilán, R.G. \& Fernández González, F. - 1998 - Astragalus sempervirens subsp. muticus (Pau) Laímz y otras novedades florísticas para la sierra de Guadarrama descubiertas en los mármoles del macizo de Peñalara - An. Jard. Bot. Madrid 56: 397-398.

Purvis, O.W., Coppins, B.J., Hawksworth, D.L. \& al. 1992 - The lichen flora of Great Britain and Ireland Nat. Hist. Mus. Publ., London

Rivas Goday, S. \& Borja Carbonell, J. -1961 - Estudio de la vegetación y flórula del macizo de Gúdar y Javalambre - An. Inst. Bot. Cavanilles 19: 3-540.

Smith, A.J.E. - 1996 - The moss flora of Britain and Ireland - Cambridge Univ. Press, Cambridge

Theurillat, J.P. \& Guisan, A. - 2001 - Potential impact of climate change on vegetation in the European alps: a review - Clim. Change 50: 77-109.

Ter Braak, C.J.F. Šmilauer, P. -2002- CANOCO Reference Manual and CanoDraw for Windows User's Guide: Software for Canonical Community Ordination (ver. 4.5). - Microcomputer Power, Ithaca NY,USA, 500 pp.

Tutin, S. \& al. (Eds.) - 1964-1993 - Flora Europaea Cambrige Univ. Press, Cambridge.

Walther, G.R., Beissner, S., Burga C.A. - 2005- Trends in the upward shift of alpine plants - J. Veg. Sci. 16: 541-548. 